\title{
Scientific production of the Revista Gaúcha de Enfermagem and research priorities in nursing
}

\author{
Maria da Graça Oliveira Crossettia \\ Luiza Maria Gerhardt ${ }^{b}$ \\ Beatriz Ferreira Waldmanc
}

DOl: http://dx.doi.org/10.1590/1983-

1447.2014.03.50165

Nursing is a social and humanistic discipline, where the development of care technologies focuses on changes in society resulting social, political, economic and historic determinants. These conditions define priorities and establish guidelines for the production of knowledge aimed at the health needs of different population groups and specific contexts.

This editorial aims to analyze the alignment of scientific production published in the Revista Gaúcha de Enfermagem (RGE), volume 35, numbers 1, 2 and 3 of 2014, with research priorities in nursing discussed and proposed in the National Nursing Research Seminar held in $2013^{(1)}$.

The goal of this brief analysis is to illicit reflection on the trends and gaps in the production of nursing knowledge, considering the National Agenda of Priorities in Health Research (ANPPS) defined as a Ministry of Health management instrument(2).

The objectives of the ANPPS(2) include: identifying the primary national and regional health research needs with a view to formulating social policies; guiding promotional initiatives through the population's health needs; guiding researchers and funders to produce studies related to national requirements and measure the impact of national research on health.

The ANPPS defined 24 sub-agendas that address priority research topics in different disciplines of knowledge ${ }^{(2-3)}$. Based on these sub-agendas, and considering state of the art nursing research, Oliveira( ${ }^{(4)}$ proposes guiding themes to define research priorities in nursing, as follows: nursing care and its subjects; cross-cutting national problems; professional skills; and research objects strengthened by induction to establish nursing research priorities. These guiding themes go beyond morbid processes and clinical problems, since they focus on the health-disease process as a whole. Of these, eleven topics have characterized the development of research in the $\operatorname{area}^{(4)}$.

The present study considered 54 original articles in the RGE that were classified according to these topics.

Analysis of the articles identified alignment with the following topics: 4 (7.41\%) with Topic 1 Health, the Environment, Work and Biosecurity in Nursing; 8 (14.81\%) with Topic 2 Evaluation of Nursing Technology and Health Economy; 2 (3.70 \%) with Topic 3 Clinical Investigation in Nursing; 5 (9.26\%) with Topic 4 Health Education and Work Management; 3 (5.55\%) with Topic 5 Health Policies and Systems; 2 (3.70\%) with Topic 6 Nursing Care in Elderly Health; 5 (9.26\%) with Topic 7 Nursing Care in Women's Health; 7 (12.96\%) with Topic 8 Nursing Care in Child and Adolescent Health; 4 (7.41\%) with Topic 9 Nursing Care in Mental Health; 2 (3.70\%) with Topic 10 Nursing Care in Communicable Diseases and 7 (12.96\%) with Topic 11 Nursing Care in Non-Communicable Diseases. Among the articles analyzed, 5 (9.26\%) were related to professional training and therefore did not fall under any topic.

\footnotetext{
- Dctor of Philosophy in Nursing from the Universidade Federal de Santa Catarina (UFSC). Lecturer of Fundamental Nursing at the Universidade do Estado do Rio de Janeiro (UERJ). Permanent Professor on the Graduate Studies Nursing Program at UFRGS. Professor on the Graduate Studies Nursing Program at UFRGS. Full Professor at the UFRGS Nursing School. Coordinator of the NECE/UFRGS. Coordinator of the Editing Committee for the Revista Gaúcha de Enfermagem. Porto Alegre, Rio Grande do Sul state, Brazil

b Nurse, PhD in Education. Coordinator of the RS branch of the Brazilian Network of Nursing and Patient Safety (REBRAENSP). Professor on the Graduate Program in Nursing Studies, Universidade Federal do Rio Grande do Sul, Brasil PhD in Biomedical Gerontology from the Pontifícia Universidade Católica do Rio Grande do Sul. Professor on the Graduate Program in Nursing Studies at the Universidade Federal do Rio Grande do Sul (UFRGS). Coordinator of the Committee for Graduate Studies in Nursing at UFRGS.
} 
This assessment of production published in the RGE shows that the direction of nursing research is in line ANPPS premises and the guiding themes for nursing research priorities proposed by Oliveira ${ }^{(4)}$. However, it also pinpoints the need to consider the issue of professional training as a guiding theme in research priorities.

This scenario confirms the fulfillment of the RGE's mission to contribute to disseminating knowledge in the field of health by publishing scientific production pertinent to Nursing and attests to its commitment to developing science and technology in caring for people.

\section{QREFERENCES}

1. Oliveira DC. Prioridades de pesquisa em saúde e em enfermagem. In: Anais do 17. Seminário Nacional de Pesquisa em Enfermagem; 2003 jun 3-5; Natal, Brasil. Natal: Associação Brasileira de Enfermagem, Seção Rio Grande do Norte; 2013. p. A123-30.

2. Ministério da Saúde, Secretaria de Ciência, Tecnologia e Insumos Estratégicos, Departamento de Ciência e Tecnologia (BR). Agenda nacional de prioridades de pesquisa em saúde. 2. ed. Brasília: Ministério da Saúde; 2008. 68 p. Série B. Textos Básicos em Saúde.

3. Ministério da Saúde, Secretaria de Ciência, Tecnologia e Insumos Estratégicos, Departamento de Ciência e Tecnologia (BR). Pesquisa em saúde no Brasil. Rev Saúde Pública, 2008; $42(4): 773-5$.

4. Oliveira. DC. Prioridades de pesquisa em saúde e as áreas de conhecimento em enfermagem. Rev Enferm UERJ, 2013 dez;21(nesp. 1):567-8. 